\title{
Hubungan Pendampingan Suami dengan Tingkat Kecemasan Ibu Primi Gravidarum saat Menghadapi Persalinan
}

\author{
Khusnul Nikmah ${ }^{1}$ \\ ${ }^{1}$ Program Studi Diploma III Kebidanan Universitas Islam Lamongan \\ Corresponding author: Khusnul Nikmah (khusnulnikmah.80@gmail.com)
}

Received 19 September 2018; Accepted 20 September 2018; Published 24 September 2018

\begin{abstract}
ABSTRAK
Dukungan atau keterlibatan suami sangat di perlukan selama proses persalinan, mulai fase laten sampai dengan persalinan. Beberapa hal yang dapat dilakukan keluarga terutama suami selama proses persalinan yaitu memberikan dukungan emosi, memberikan dorongan dan kenyamanan. Perhatian yang didapat seorang ibu pada masa pra persalinan akan terus dikenang terutama bagi mereka yang pertama kali melahirkan perlu pendampingan agar tidak terjadi kecemasan. Tujuan dalam penelitian ini adalah untuk mengetahui hubungan pendampingan suami dengan tingkat kecemasan ibu primi gravidarum saat menghadapi persalinan. Desain penelitian yang digunakan adalah analitik dengan pendekatan Cross Sectional, populasinya adalah ibu hamil dalam proses persalinan. Waktu yang digunakan bulan Juni 2018 sampai dengan Agustus 2018 sejumlah 24 ibu primi gravidarum. Pengambilan sample dilakukan secara Purposive Sampling, variabel Independen pendampingan suami dan variabel Dependen tingkat kecemasan ibu primi gravidarum saat menghadapi persalinan. Data dikumpulkan menggunakan kuesioner, lembar observasi skala HARS dan dianalisis melalui uji statistik Koofisiensi Kontingensi dengan tingkat signifikan 0,05. Hasil penelitian menunjukkan bahwa lebih dari sebagian didampingi suami $(58,3 \%)$, dan hampir sebagian tidak cemas pada ibu primi gravidarum saat menghadapi persalinan $(41,7 \%)$. Hasil analisa data secara keseluruhan $(p<\alpha)$ yaitu $(0,027<0,05)$ maka $\mathrm{H}_{0}$ ditolak yang artinya ada hubungan antara pendampingan suami dengan tingkat kecemasan saat menghadapi persalinan. Untuk mengurangi rasa cemas pada ibu primi gravidarum saat proses persalinan disarankan pada petugas kesehatan untuk mengikut sertakan anggota keluarga dalam proses persalinan dan menjelaskan pada anggota keluarga dan ibu primigravidarum tentang pentingnya keikutsertaan anggota keluarga dalam proses persalinan biar waktu persalinan ibu tidak cemas.
\end{abstract}

Kata kunci: Pendampingan suami, kecemasan ibu primi, persalinan

Copyright @ 2018 STIKes Surya Mitra Husada

All rights reserved.

This is an open-acces article distributed under the terms of the Creative Commons Attribution-ShareAlike 4.0 International License.

\section{PENDAHULUAN}

Tingginya Angka Kematian Ibu merupakan salah satu permasalahan yang dihadapi bangsa Indonesia terutama tenaga kesehatan. Kenyataan ini menempati urutan tertinggi di ASEAN dimana 
upaya penurunan Angka Kematian Ibu ditempatkan sebagai prioritas utama dalam pembangunan kesehatan (Manuaba,2001).

Berdasarkan data dari SDKI (2015), Angka Kematian Ibu di Indonesia adalah 305 per 100.000 kelahiran hidup, sedangkan target Sustain Development Goals (SDG's) adalah tahun 2030 AKI Indonesia mencapai 70 per 100.000 kelahiran hidup.

Perkembangan kejiwaan ibu hamil dan ibu bersalin dapat mengalami beberapa perubahan. Pada saat kehamilan yang diharapkan dapat mendorong kegairahan keluarga dan mengharapkan tidak terjadi apapun atau hal-hal yang tidak diinginkan selama hamil. Pada saat pertolongan persalinan pertama kesabaran lebih diperlukan karena penderita / ibu bersalin belum mempunyai pengalaman bersalin sehingga dapat mengkoordinasi kekuatan His dan mengejan (Manuaba, 2001).

Perhatian yang didapat seorang ibu pada masa pra persalinan akan terus dikenang terutama bagi mereka yang pertama kali melahirkan atau mengalami proses persalinan, jika pengalaman itu terasa menyenangkan maka akan menjadi modal bagi kelancaran persalinan. Jika yang terjadi adalah sebaliknya biasanya itu menjadi pengalaman buruk yang mungkin akan membuat mereka jera dan dapat mengganggu proses persalinan.

Sejak beberapa tahun yang lalu baik pasien maupun penolong persalinan ingin agar perasaan takut, ketegangan nyeri dalam persalinan itu dapat dihilangkan agar ibu tersebut bukan saja tidak menjerit-jerit karena ketakutan dan kesakitan akan tetapi dapat turut aktif dan berperan serta dalam proses persalinan, sehingga persalinan dapat berlangsung dengan baik dan dalam suasana yang tenang.

Pendamping terutama orang terdekat ibu selama proses persalianan ternyata dapat membuat persalinan menjadi lebih singkat, nyeri berkurang, robekan jalan lahir lebih jarang serta nilai APGAR pun menjadi lebih baik (Iskandar, 2005).

Hasil penelitian di Iran menunjukkan bahwa sebagian besar ibu bersalin $(88,4 \%)$. Para suami sebesar $82,1 \%$ menginginkan suami mendampingi saat bersalin karena dapat mengurangi intensitas nyeri yang dirasakan ibu akibat kontraksi uterus dan 52,5\% ibu hamil menghadapi kelahiran anak pertama berada pada kategori kecemasan rendah jika suami memberikan dukungan saat bersalin. Kejadian depresi postpartum pada kelompok ibu bersalin yang tidak didampingi suami sebesar $15,6 \%$, jika didampingi suami hanya $1,3 \%$. Suami perlu mempunyai pengetahuan dan keterampilan apa yang harus dilakukan dalam memberikan dukungan tersebut, hal ini bisa didapat melalui penyuluhan atau pendidikan. http://www.sejiwa.blogspot.com/2009/03/.

Penelitian lain terhadap 200 ibu melahirkan di rumah sakit yang berada di 5 kota besar di Indonesia, diperoleh fakta sekitar $86,2 \%$ menyatakan perasaan senang dan bahagia karena selama proses persalinan didampingi oleh suami dan sisanya merasa senang bila didampingi keluarga khususnya ibu kandung (Aswiningrum).

Berdasarkan survey pendahuluan, dari 28 ibu bersalin di BPM "M" Jl. Menur II Surabaya periode bulan Januari sampai Maret 2018, terdapat 24 ibu bersalin yang didampingi Suami dan 4 ibu bersalin yang tidak didampingi Suami. Dari 28 ibu bersalin yang didampingi Suami merasa tenang pada saat menghadapi proses persalinannya, sedangkan 4 ibu bersalin lainnya mengalami tingkat kecemasan / merasa cemas karena pada proses persalinannya tidak didampingi Suami, karena kebanyakan pada saat mengalami proses persalinan Suaminya sedang sibuk bekerja.

Banyaknya penelitian yang mendukung orang kedua pada saat persalinan berlangsung. Penelitian ini menunjukkan bahwa ibu merasakan kehadiran orang kedua tersebut sebagai pendamping penolong persalinan atau bidan akan memberikan kenyamanan, penelitian juga menunjukkan bukti bahwa kehadiran seorang pendamping pada saat persalinan dapat menimbulkan efek positif terhadap hasil persalinan dalam arti dapat menurunkan morbiditas, mengurangi rasa sakit, persalinan yang lebih singkat dan menurunnya persalinan dengan operasi seksio cesaria. Penelitian lain juga menjelaskan bahwa kehadiran seorang pendamping persalinan dapat membesarkan hati. Kehadiran orang kedua atau pendamping persalinan atas pilihan ibu sendiri disamping penolong persalinan sangat bermanfaat. (Depkes RI, 2001)

Peran yang dapat suami lakukan dalam proses persalinan antara lain mengatur posisi ibu, memberikan nutrisi dan cairan, mengalihkan perhatian ibu dari rasa nyeri selama proses persalinan, mengukur waktu kontraksi, mengusap-usap punggung ibu, menjadi titik fokus, bernapas bersama ibu saat kontraksi, menginformasikan kemajuan persalinan, memberikan dorongan spiritual, memberi dukungan moral, menghibur dan memberi dorongan semangat (Lucianawaty, 2009). Nasehat yang 
dapat diberikan kepada suami untuk kehamilan istrinya agar dapat terjaga dan terawat sampai persalinan, sangat dibutuhkan partisipasi suami yang dibutuhkan antara lain : (1) Memberikan perhatian dan kasih sayang kepada istri, (2) Mendorong dan mengantar istri untuk memeriksakan kehamilan kesehatan terdekat minimal 4 kali selama kehamilan, (3) Memenuhi gizi bagi istrinya agar tidak terjadi kekurangan gizi.

Dukungan atau keterlibatan Suami sangat di perlukan selama proses persalinan, mulai dari fase laten sampai dengan saat persalinan. Melihat uraian di atas maka peneliti tertarik untuk mengadakan penelitian tentang "Hubungan Antara Pendampingan Suami dengan Tingkat Kecemasan Ibu Primi Gravidarum saat Menghadapi Proses Persalinan".

\section{METODE}

Penelitian ini menggunakan rancangan penelitian Analitik Observasional. Metode yang digunakan cross sectional bertujuan untuk mengetahui Hubungan Pendampingan Suami dengan Tingkat Kecemasan Ibu Primigravidarum saat Menghadapi Proses Persalinan di BPM "M" Jl. Menur II Surabaya dan sampel penelitian ini adalah Ibu Bersalin di BPM "M" Jl. Menur II Surabay bulan Juni - Agustus 2018 yang berjumlah 24 Ibu Bersalin. Tehnik samplingnya menggunakan Purposive Sampling.

\section{HASIL DAN PEMBAHASAN}

\section{Data Khusus}

1. Karakteristik Berdasarkan Pendampingan Suami

Tabel 1 Distribusi Responden Berdasarkan Pendampingan Suami saat menghadapi proses persalinan di BPM “M” Jl. Menur II Surabaya

\begin{tabular}{clcc}
\hline No. & \multicolumn{1}{c}{ Pedampingan } & Frekuensi & Presentase \\
\hline 1. & Didampingi Suami & 14 & 58,3 \\
2. & Tidak Didampingi Suami & 10 & 41,7 \\
\hline \multicolumn{2}{l}{ Total } & 24 & 100 \\
\hline
\end{tabular}

Berdasarkan tabel 1 diatas dapat dilihat bahwa dari 24 ibu primi gravidarum lebih dari sebagian yang didampingi suami dalam persalinan sebanyak $14(58,3 \%)$ dan sebagian kecil yang tidak didampingi suaminya sebanyak $10(41,7 \%)$.

2. Karakteristik Berdasarkan Kecemasan Ibu

Tabel 2 Distribusi Responden Berdasarkan Kecemasan saat menghadapi Persalinan di BPM "M" Jl. Menur II Surabaya

\begin{tabular}{clcc}
\hline No. & \multicolumn{1}{c}{ Kecemasan } & Frekuensi & Presentase \\
\hline 1. & Tidak Cemas & 10 & 41,7 \\
2. & Cemas Ringan & 5 & 20,8 \\
3. & Cemas Sedang & 6 & 25 \\
4. & Cemas Berat & 3 & 12,5 \\
\hline & Total & 24 & 100 \\
\hline
\end{tabular}

Berdasarkan tabel 2 diatas dapat dilihat bahwa dari 24 Ibu primi gravidarum hampir sebagian tidak cemas sebanyak $10(41,7 \%)$, dan sebagian kecil mengalami cemas berat sebanyak $3(12,5 \%)$. 
3. Hubungan Pendampingan suami dengan Kecemasan Ibu Primigravidarum saat Menghadapi Persalinan.

Tabel 3 Distribusi Silang Hubungan antara Pendampingan Suami dengan Kecemasan ibu primigravidarum saat menghadapi persalinan di BPM "M" Jl. Menur II Surabaya

\begin{tabular}{|c|c|c|c|c|c|c|}
\hline \multirow[b]{2}{*}{ No } & \multirow[b]{2}{*}{$\begin{array}{l}\text { Pendampingan } \\
\text { Suami }\end{array}$} & \multicolumn{4}{|c|}{ Kecemasan } & \multirow[b]{2}{*}{$\begin{array}{c}\text { Jumlah } \\
(\%)\end{array}$} \\
\hline & & $\begin{array}{c}\text { Cemas Berat } \\
(\%)\end{array}$ & $\begin{array}{c}\text { Cemas Sedang } \\
(\%)\end{array}$ & $\begin{array}{c}\text { Cemas Ringan } \\
(\%)\end{array}$ & $\begin{array}{c}\text { Tidak Cemas } \\
(\%)\end{array}$ & \\
\hline 1. & $\begin{array}{c}\text { Tidak } \\
\text { Didampingi }\end{array}$ & $2(20 \%)$ & $5(50 \%)$ & $2(20 \%)$ & $1(10 \%)$ & $\begin{array}{c}10(100 \%) \\
14\end{array}$ \\
\hline 2. & Didampingi & $1(7,1 \%)$ & $1(7,1 \%)$ & $3(21,4 \%)$ & $9(64,3 \%)$ & $(100 \%)$ \\
\hline \multirow{2}{*}{\multicolumn{2}{|c|}{ Jumlah }} & $3(12,5 \%)$ & $6(25 \%)$ & $5(20,8 \%)$ & $10(41,7 \%)$ & $\begin{array}{c}24 \\
(100 \%)\end{array}$ \\
\hline & & itung $=9,18$ & & 0,027 & 0,05 & \\
\hline
\end{tabular}

Dari tabel 3 distribusi silang diatas dapat dijelaskan bahwa dari 10 ibu primi gravidarum yang tidak didampingi dengan tidak cemas 1 (10\%), cemas ringan $2(20 \%)$, cemas sedang $5(50 \%)$ dan cemas berat $2(20 \%)$ sedangkan ibu primi gravidarum yang didampingi dengan tidak cemas 9 $(64,3 \%)$, cemas ringan $3(21,4 \%)$, cemas sedang $1(7,1 \%)$ dan cemas Berat $1(7,1 \%)$. Dilakukan Uji Statistik dengan menggunakan Uji Koefisien Kontingensi dengan tingkat kemaknaan ( $\alpha$ ) yaitu 0,05 . Berdasarkan hasil analisa data jawaban kuesioner dengan menggunakan desain penelitian analitik dengan tarif signifikan 0,05. Didapat hasil dengan $X^{2}$ hitung (Value) $=9,189$ dan $\rho=0,027$. Kemudian bila $\rho \leq \alpha(0,027 \leq 0,05)$ dan $\mathrm{X}^{2}$ hitung $\geq \mathrm{X}^{2}$ tabel $(9,189 \geq 7,82)$. Maka $\mathrm{H}_{0}$ ditolak yang artinya nilai $\mathrm{p}$ sebesar 0,027 maka $\mathrm{p}<\alpha(0,05)$ berarti ada hubungan pendampingan suami dengan tingkat kecemasan ibu primi gravidarum saat menghadapi persalinan di BPM "M" Jl. Menur II Surabaya

\section{PEMBAHASAN}

\section{Pendampingan Suami}

Berdasarkan tabel 1 diatas dapat dilihat bahwa dari 24 ibu primi gravidarum lebih dari sebagian yang didampingi suami dalam persalinan sebanyak $14(58,3 \%)$ dan sebagian kecil yang tidak didampingi suaminya sebanyak $10(41,7 \%)$.

Pendampingan adalah dimana Suami bertanggung jawab untuk mempersiapkan kekuatan mental istri untuk melahirkan karena saat-saat itu adalah perjuangan hidup dan mati istri bagi keluarganya. Suami bisa ikut hadir saat proses persalinan, kehadiran suami ini walau sekedar menemani, memegang tangan istri, dan membisikkan kata-kata menghibur pada istri akan memberikan dorongan kekuatan mental ekstra bagi istri. Walaupun tak dapat mengurangi rasa sakit namun kekuatan mental yang diperoleh istri akan sebagian yang bekerja sebanyak 12 (50\%), dan sebagian kecil yang bekerja membuatnya lebih kuat menahan sakit, yang pada akhirnya akan mempermudah proses persalinan. ( Enkin, et al, 2000)

Kebanyakan Ibu primi gravidarum yang tidak didampingi suami dalam proses persalinan mengakibatkan ibu merasa cemas, dan tegang. Karena ketegangan akan menyebabkan otot bertambah kaku sehingga akan mempersulit proses pembukaan. Kehadiran pendampingan persalinan dapat memberikan dorongan bagi ibu agar tidak cemas, memberikan kenyamanan, ketenangan, dan semangat. Rasa sayang dan simpati yang diberikan oleh suami pada istri pada saat melahirkan akan memberikan kekuatan tersendiri yang dapat memicu semangat istri untuk lebih kuat dalam melalui proses persalinan. Jadi pendampingan sangat berperan aktif dalam mendukung proses persalinan sehingga persalinan dapat berlangsung cepat, namun keadaan di lapangan kecemasan tersebut sulit dihilangkan bagi ibu yang sifatnya selalu memikirkan keadaan lingkungan baik berdasarkan resiko kelahiran itu sendiri misalkan kematian, memikirkan administrasi, apalagi di saat dia mendengarkan persalinan tersebut harus dilanjutkan dengan jalan operasi, maka dari itu kecemasan ibu tersebut akan 
semakin memuncak. Faktor-faktor yang mempengaruhi peran pendamping persalinan antara lain sosial, ekonomi, budaya, lingkungan, pengetahuan, umur dan pendidikan.

Partisipasi suami yang cukup tinggi dalam pendampingan istri menunjukkan bahwa suami menyadari akan peran yang bisa dilakukannya dalam memberikan dukungan fisik dan dorongan moral kepada istri yang sedang melahirkan. Sehingga pada waktu proses persalinan di BPM "M" Jl. Menur II Surabaya ini banyak para suami yang melakukan pendampingan dan dukungan pada istrinya selama proses persalinan istrinya dan kami sebagai tenaga kesehatan juga menganjurkan pada keluarga atau suami untuk mendampingi ibu-ibu yang mau melahirkan ditempat kami.

\section{Kecemasan Ibu Primi Gravidarum Saat Menghadapi Persalinan}

Berdasarkan tabel 2 diatas dapat dilihat bahwa dari 24 Ibu primi gravidarum hampir sebagian tidak cemas sebanyak 10 (41,7 \%), dan sebagian kecil mengalami cemas berat sebanyak $3(12,5 \%)$.

Kecemasan (anxietas) adalah suatu keadaan dimana individu mengalami perasaan yang sulit (kecemasan atau ketakutan) dan aktifitas saraf otonom dalam berespon terhadap ancaman yang tidak jelas, non spesifik.(Carpenito,2006).

Kecemasan suatu perasaan yang sifatnya umum, dimana seseorang merasa ketakutan atau kehilangan kepercayaan diri yang tidak jelas asal maupun wujudnya. Beberapa ahli sosial berpendapat bahwa wanita memiliki risiko yang lebih besar untuk menderita gangguan kecemasan karena posisi mereka dalam masyarakat dan sifat - sifat dasar mereka dalam menjalani hubungan dengan orang lain.

Primi gravidarum adalah seseorang wanita yang hamil pertamakali dan merasakan kecemasan yang lebih dari pada wanita yang sudah hamil sebelumnya. ( Depkes RI 2001 )

Rasa takut dan kecemasan akan meningkatkan respon seseorang terhadap rasa sakit. Rasa sakit kepada sesuatu yang tidak diketahui, rasa takut terhadap kesendirian dalam mengatasi suatu pengalaman seperti persalinan dan rasa takut akan kegagalan dalam mengatasi kecemasan akan menambah kecemasan seseorang (Carpenito, 2006).

Menurut karakteristik Ibu primi gravidarum sesuai dengan tingkat pendidikannya didapatkan Ibu primi gravidarum terbanyak tingkat pendidikan adalah Menengah dengan kapasitas Ibu primi gravidarum $12(50 \%)$. Dengan tingkat pendidikan tersebut maka dapat dikatakan bahwa tingkat pendidikan Ibu primi gravidarum adalah tinggi. Hal ini menunjukkan bahwa dengan tingginya tingkat pendidikan seseorang akan memperingan tingkat kecemasan seseorang. Dalam hal ini wanita sebagai calon seorang ibu akan melahirkan keturunan dari suatu generasi, sehingga untuk menghasilkan generasi yang berkualitas tentunya harus dimulai sejak dalam masa kehamilan. Terlebih kehamilan tersebut merupakan peristiwa yang pertama kali. Karena kebanyakan Ibu primi gravidarum mengalami cemas yang sangat berat karena informasi yang didapat dari pengalaman dan cerita orang yang kurang baik tentang persalinan. Bahwa persalinan itu akan terasa sakit, pertaruhan antara hidup dan mati apalagi kalau pertamakali persalinan akan membutukan proses dan kesakitan yang sangat lama dan jalan lahir akan banyak jahitan. Dan faktor predeposisi juga mempengaruhi kecemasan seperti psikoanalitik, interpesonal, perilaku, dan biologis.

Rasa cemas dapat timbul akibat kekhawatiran akan proses kelahiran yang aman untuk dirinya dan bayinya maka dari itu di BPM "M" J1 Menur II Surabaya setiap ibu yang bersalin dianjurkan untuk didampingi baik suami maupun keluarga biar bisa mengurangi rasa cemas pada ibu yang mau bersalin.

\section{Hubungan Antara Pendampingan Suami Dengan Tingkat Kecemasan ibu primi gravidarum saat menghadapi proses persalinan.}

Berdasarkan table 3 dilakukan uji statistic dengan hasi uji Koofisiensi Kontingensi dapat disimpulkan bahwa pendampingan suami saat menghadapi proses persalinan mendapatkan tingkat kemaknaan $\rho \leq \alpha(0,027 \leq 0,05)$ maka $\mathrm{H}_{0}$ di tolak, sehingga dapat disimpulkan bahwa pendampingan suami ada hubungan dengan tingkat kecemasan ibu primi gravidarum pada saat menghadapi persalinan. Hal ini sesuai teori bahwa Pendampingan adalah dimana Suami atau keluarga bertanggung jawab untuk mempersiapkan kekuatan mental istri untuk melahirkan karena saat-saat itu adalah perjuangan hidup dan mati istri bagi keluarganya. Suami atau keluarga bisa ikut hadir saat proses 
persalinan, kehadiran suami ini walau sekedar menemani, memegang tangan istri, dan membisikkan kata-kata menghibur pada istri akan memberikan dorongan kekuatan mental ekstra bagi istri. Walaupun tak dapat mengurangi rasa sakit namun kekuatan mental yang diperoleh istri akan membuatnya lebih kuat menahan sakit, yang pada akhirnya akan mempermudah proses persalinan (Enkin, et al, 2000)

Kecemasan suatu perasaan yang sifatnya umum, dimana seseorang merasa ketakutan atau kehilangan kepercayaan diri yang tidak jelas asal maupun wujudnya. Beberapa ahli sosial berpendapat bahwa wanita memiliki risiko yang lebih besar untuk menderita gangguan kecemasan karena posisi mereka dalam masyarakat dan sifat - sifat dasar mereka dalam menjalani hubungan dengan orang lain.

Kehadiran pendampingan persalinan dapat memberikan dorongan bagi ibu untuk mengurangi kecemasan khususnya pendampingan dari seorang suami, namun keadaan di lapangan kecemasan tersebut sulit dihilangkan bagi ibu yang sifatnya selalu memikirkan keadaan lingkungan baik berdasarkan resiko kelahiran itu sendiri misalkan kematian, memikirkan administrasi, apalagi di saat dia mendengarkan persalinan tersebut harus dilanjutkan dengan jalan operasi, maka kecemasan ibu tersebut akan semakin memuncak, dan faktor predisposisi juga mempengaruhi kecemasan seperti psikoanalitik, interpesonal, perilaku, dan biologis. Maka meskipun pendampingan oleh suami kurang bisa mengurangi kecemasan tersebut, suami juga harus mengerti keadaan ibu tersebut untuk menunjang terlaksananya proses persalinan dengan cepat walaupun masih ada rasa kecemasan. Dan Faktor-faktor yang mempengaruhi peran pendamping persalinan antara lain sosial, ekonomi, budaya, lingkungan, pengetahuan, umur dan pendidikan.

Didampingi keluarga, apalagi suami, saat melahirkan, tentu membuat Ibu lebih tenang. Karena, selain dukungan mental, pendamping juga membantu memastikan rencana persalinan yang sudah disusun bersama berjalan sesuai yang Ibu inginkan. Ibu tinggal konsentrasi pada persalinan saja. Urusan lain, biar suami yang ambil alih. Jadi, Ibu tidak stress memikirkan ini dan itu. Ibu hamil dengan tingkat stress rendah, lebih memungkinkan melakukan persalinan alami. Dalam penelitian ini ditemukan bahwa kehadiran suami akan membawa ketenangan dan menjauhkan sang ibu dari kecemasan yang dapat mempersulit proses kelahiran dan persalinan, kehadiran suami akan membawa pengaruh positif secara psikologis, dan berdampak positif pula pada kesiapan ibu secara fisik pada saat bersalin.

\section{KESIMPULAN}

Hasil Uji Statistik dengan menggunakan Uji Koefisien Kontingensi di dapatkan nilai $\mathrm{X}^{2}$ hitung $\geq \mathrm{X}^{2}$ tabel $(9,189 \geq 7,82)$. Maka $\mathrm{H}_{0}$ ditolak yang artinya nilai $\mathrm{p}$ sebesar 0,027 maka $\mathrm{p}<\alpha(0,05)$ berarti ada hubungan pendampingan suami dengan tingkat kecemasan ibu primi gravidarum saat menghadapi persalinan di BPM “M” Jl. Menur II Surabaya

\section{DAFTAR PUSTAKA}

Arikunto. (2006). Prosedur Penelitian Suatu Pendekatan Praktik. Jakarta: Rineka Cipta

Carpenito. (2006). Diagnosa Keperawatan. Jakarta

Dep Kes RI. (2002). Catatan Tentang Perkembangan dalam Praktek Kebidanan. Jakarta http://www.sejiwa.blogspot.com/2009/03/

JNPK. KR. (2002). Asuhan Persalinan Normal. Jakarta

Januadi, Judi. (2002). Mempersiapkan Persalinan Sehat. Jakarta: Puspa Swara

Manuaba, Ida Bagus Gde. (1998). Ilmu Kebidanan Penyakit Kandungan dan Keluarga Berencana untuk Pendidikna Bidan. Jakarta: EGC.

Mansjoer. (2000). Kapita Selekta Kedokteran Jilid 2. Jakarta: Media Aesculapius 
Mochtar, Rustam. (1998). Synopsis Obstetri. Jakarta: EGC

Nursalam., \& Pariani. (2003). Metodologi Riset Keperawatan. Jakarta: Info Medika Prawirohardjo Notoatmodjo. (2002). Metodologi Penelitian Kesehatan. Jakarta: Rineka Cipta

Novita. (2010). Kehamilan. http://idi.wikipedia.org. Rabu, 5 mei 2010, jam 20.00 WIB

Pusdiknas WHO JHPIEGO. (2001). Konsep Asuhan Kebidanan. Jakarta

Pusdiknas WHO JHPIEGO. (2003). Konsep Asuhan Kebidanan. Jakarta

Soekidjo, Notoatmojo. (2005). Promosi Kesehatan Teori dan Aplikasi. Jakarta: PT Rineka Cipta

Simkin P, ancketa R. (2005). Buku Saku Persalinan. Jakarta: EGC 